\title{
PREVALENCE OF ASYMPTOMATIC ABDOMINAL AORTIC ANEURYSM IN PATIENTS WITH CAROTID STENOSIS
}

\author{
Slavco Toncev ${ }^{1}$, Dejan Aleksic ${ }^{2}$, Gordana Toncev²
}

${ }^{1}$ Center of Vascular Surgery, Clinical Center Kragujevac, Faculty of Medical Sciences Kragujevac, University of Kragujevac

${ }^{2}$ Clinic of Neurology, Clinical Center Kragujevac, Faculty of Medical Sciences Kragujevac, University of Kragujevac

\section{PREVALENCA ASIMPTOMATSIKE ANEURIZME ABDOMINALNE AORTE KOD PACIJENATA SA KAROTIDNOM STENOZOM}

Slavčo Tončev ${ }^{1}$, Dejan Aleksić ${ }^{2}$ Gordana Tončev²

${ }^{1}$ Centar za vaskularnu hirurgiju, Klinički centar Kragujevac, Fakultet Medicinskih nauka, Univerzitet u Kragujevcu

${ }^{2}$ Klinika za neurologiju, Klinički centar Kragujevac, Fakultet Medicinskih nauka, Univerzitet u Kragujevcu

\begin{abstract}
The aim of this study was to demonstrate the prevalence of abdominal aortic aneurysm in patients with carotid disease and to analyse the influence of cardiovascular risk factors for abdominal aortic aneurysm. Methods: Ultrasound for abdominal aortic aneurysm was performed in 200 patients (112 men and 88 women, mean age 65.72 7.71 years) with known carotid disease. The primary cardiovascular risk factors (age, sex, hypertension, diabetes, dyslipidaemia and smoking) were analysed. Results: We found that $15.5 \%$ of patients with carotid stenosis also had abdominal aortic aneurysm. The prevalence of abdominal aortic aneurysm was higher in men (22.23\%) than in women (6.81\%). There was no correlation between the severity of carotid disease and the diameter of the abdominal aortic aneurysm ( $p>0.05)$. Advanced age and smoking were independent risk factors for abdominal aortic aneurysm. Conclusion: These results demonstrate that the prevalence of abdominal aortic aneurysm is higher in patients with carotid disease than in the general population. Patients with known carotid disease may be candidates for selective screening for abdominal aortic aneurysm detection.
\end{abstract}

Keywords: abdominal aortic aneurysm, carotid stenosis, risk factors

\section{SAŽETAK}

Cilj ovog istraživanja jeste utvrđivanje prevalence aneurizme abdominalne aorte kod pacijenata sa karotidnom stenozom $i$ analiza uticaja glavnih kardiovaskularnih faktora rizika na razvoj aneurizme abdominalne aorte.

Ultrazvuk stomaka za otkrivanje aneurizme abdominalne aorte je primenjen na 200 pacijenata (112 muškaraca $i \quad 88$ žena), prosečne starosti od $65.72 \pm 7.71$ godine sa već potvrđenom bolešću karotidnih arterija. Analizirani su glavni kardiovaskularni faktori rizika (godine, pol, hipertenzija, dijabetes, dislipidemija i pušenje).

Pronašli smo da $15.5 \%$ pacijenata sa karotidnim stenozom ima aneurizmu abdominalne aorte. Prevalenca aneurizme abdominalne aorte bila je veća kod muškaraca (22.23\%) nego kod žena (6.81\%). Nije bilo korelacije između težine karotidne stenoze i dimenzija aneurizme abdominalne aorte ( $p>0.005)$. Starija životna dob i pušenje su nezavisni faktori rizika za nastanak aneurizme abdominalne aorte.

Rezultati ukazuju da je prevalenca aneurizme abdominalne aorte veća kod pacijenata sa karotidnom stenozom nego u opštoj populaciji. Pacijenti sa potvrđenom karotidnom stenozom mogu biti ciljna grupa za skrining pregled za postojanje aneurizme abdominalne aorte.

Ključne reči: aneurizma abdominalne aorte, karotidna stenoza, faktori rizika

\section{INTRODUCTION}

Carotid stenosis and abdominal aortic aneurysm (AAA) are frequent ailments in the elderly. It was previously thought that these illnesses were caused by atherosclerosis. However, despite that these two illnesses share the majority of their risk factors, research has shown that aneurysmal disease pathogenetically differs from occlusive artery disease (1-3). Occlusive artery disease affects the intima and partially media and is strongly associated with atherosclerosis. On the other hand, aortic aneurysmal

\section{Q⿻日土ำ}

disease affects the media and adventitia and leads to degeneration of the elastin and collagen; however, compared to occlusive disease, it has a weaker association with atherosclerosis (4). The disease is usually asymptomatic until the aneurysm ruptures, in which case the mortality rate is high, even with surgical intervention. Early diagnosis of asymptomatic AAA significantly reduces mortality in these patients.

Ultrasonography of the abdomen is an accurate, realistic and widely accepted method for detecting AAA 
that has a sensitivity and specificity of almost 100\% (5). Screening of the general population with elective surgical intervention reduces the mortality caused by AAA, but the screening process is expensive. Furthermore, there is some disagreement as to which subpopulations should be screened for AAA (6).

The aim of this study is to explore the prevalence of AAA in patients who were previously diagnosed with carotid disease and to analyse the influence of major cardiovascular risk factors for the development of AAA.

\section{MATERIALS AND METHODS}

Between January 2006 and October 2008, ultrasound of the abdominal aorta and carotid arteries was performed in 200 patients (112 males and 88 females) who were previously diagnosed carotid disease. The mean age for all patients was $65.72 \pm 7.71$ (range from 45 to $81 ; 65.55 \pm 7.91$ for men and $65.94 \pm 7.48$ for women).

The registered risk factors were common for atherosclerosis and included the following: hypertension, diabetes, dyslipidaemia and smoking. Patients were considered hypertensive if they were taking anti-hypertensive therapy (drugs or diet) or had a blood pressure over 140/90 mm Hg on at least two different occasions. A diabetes diagnosis was made for patients who were undergoing endocrinology therapy or were on a modified diet; with an overall cholesterol value over $5.7 \mathrm{mmol} / \mathrm{L}$, LDL cholesterol over $3.5 \mathrm{mmol} / \mathrm{L}$ and HDL cholesterol below $1.81 \mathrm{mmol} / \mathrm{L}$. Patients were classified as current smokers, former smokers (smoked in the past, but not smoking for at least 5 years) or non-smokers.

Carotid disease was diagnosed using a $7.5 \mathrm{MHz}$ probe with a Shimatzu SDU 2200 ultrasound device according to the criteria for determining the level of carotid artery stenosis based on the peak systolic velocity and end-diastolic velocity. Patients with carotid stenosis were assigned to one of two groups, the symptomatic or asymptomatic carotid stenosis group, according to initial reports on the carotid arteries, anamnesis and neurological status.

Symptomatic patients had a history of stroke or a transitory ischaemic attack, or they had a focal neurological disorder.

Asymptomatic patients were recruited from a group of patients who had visited the vascular surgeon because of peripheral vascular disease, on which occasion their carotid arteries were examined and asymptomatic carotid disease was diagnosed. Symptomatic carotid stenosis was diagnosed in 86 patients (47 men and 39 women; mean age of $66.98 \pm 6.72$; range from 55 to 79 ; men $66.61 \pm 6.83$; women $67.41 \pm 6.64)$, whereas asymptomatic carotid stenosis was diagnosed in 114 patients (62 men and 49 women; mean age of $64.78 \pm 8.28$; range from 45 to 81 ; men $64.78 \pm 8.34$; women $64.77 \pm 8.22$ ). The patients with carotid stenosis were further divided into 7 subgroups according to the following criteria provided by Filis et al. 2002 (7): a
Table 1. Distribution of patients with carotid stenosis by sex and age

\begin{tabular}{|l|l|l|l|l|l|}
\hline & $<55$ & $55-64$ & $65-74$ & $>74$ & Total \\
\hline $\begin{array}{l}\text { Asymptomatic } \\
\text { carotid stenosis }\end{array}$ & 9 & 22 & 47 & 8 & 86 \\
Men/Women & $6 / 3$ & $13 / 9$ & $25 / 22$ & $3 / 5$ & $47 / 39$ \\
\hline $\begin{array}{l}\text { Symptomatic } \\
\text { carotid stenosis }\end{array}$ & 21 & 34 & 50 & 9 & 114 \\
Men/Women & $14 / 7$ & $17 / 17$ & $29 / 21$ & $5 / 4$ & $65 / 49$ \\
\hline Total & 30 & 56 & 97 & 17 & 200 \\
\hline
\end{tabular}

reduced lumen in at least one carotid artery resulting from occlusion within the following ranges: up to 50\%, 50-59\%, $60-69 \%, 70-79 \%, 80-89 \%, 90-99 \%$ or complete occlusion $(100 \%)$. If a patient had bilateral carotid disease, only the carotid artery with more pronounced stenosis was included in the statistics. The patient distribution by sex, age and type of carotid stenosis is presented in Table 1.

A 3.5 MHz probe with a Shimatzu SDU 2200 ultrasound device measured the largest transverse and anteroposterior diameters of the infrarenal abdominal aorta. The patients were classified according to the findings in the following 3 categories (7): normal aorta (diameter less than $27 \mathrm{~mm}$ ), dilated aorta (diameter of 27-29 mm) or aneurysm (diameter over $29 \mathrm{~mm}$ ). The patients with aneurysm were classified according to the aneurysm diameter into the following 3 categories: diameter of 30-39 mm, diameter of 40-49 $\mathrm{mm}$, and diameter equal to or exceeding $50 \mathrm{~mm}$. Patients with an AAA over $40 \mathrm{~mm}$ underwent a subsequent $\mathrm{CT}$ of the abdomen, and patients with an aneurysm exceeding 50 $\mathrm{mm}$ were considered for surgical intervention. The finding of an abdominal aorta was correlated with the most significant risk factors for atherosclerosis.

\section{Statistical analysis}

SPSS v7.5 was used for the statistical analysis. As for the descriptive statistics, the mean \pm standard deviation were used for continuous variables, whereas the number and percentage were used for nominal variables. The $\mathrm{X}^{2}$ test was used for comparisons between nominal variables, whereas the t-test was used for comparisons between continuous variables. Correlations were calculated using a univariate correlation analysis. A multivariate correlation model was used to examine the variables that independently affected the onset of AAA.

\section{RESULTS}

The average diameter of the abdominal aorta in the 200 examined patients was $28.14 \pm 10.34 \mathrm{~mm}$ (range from 18 to $70 \mathrm{~mm}$ ). On average, men had a significantly larger abdominal aorta diameter compared with women $(30.19 \pm 11.24$ vs. $25.52 \pm 8.45$; t-test, $\mathrm{p}=0.001)$. The majority of the patients (135 patients, $67.5 \%$; 62 men and 73 women) had a normal aorta diameter, with an average of $22.35 \pm 2.95 \mathrm{~mm}$. An ectatic aorta was found in 34 patients (17\%; 15 men 
Table 2. Aortic diameters in patients with carotid stenosis

\begin{tabular}{|l|l|l|l|}
\hline & Definition $(\mathrm{mm})$ & Total & $\%$ \\
\hline Normal aorta & $<27$ & 135 & 67.5 \\
\hline Ectatic aorta & $27-29$ & 34 & 17 \\
\hline AAA & $>29$ & 31 & 15.5 \\
\hline
\end{tabular}

Table 3. Prevalence of abdominal aortic aneurysm related to sex and age

\begin{tabular}{|l|l|l|l|}
\hline Age & Total & AAA & Prevalence \% \\
\hline$<55$ & 30 & 1 & 3.33 \\
Men & 20 & 1 & 5 \\
Women & 10 & - & - \\
\hline $55-64$ & 56 & 3 & 5.36 \\
Men & 30 & 2 & 6.67 \\
Women & 26 & 1 & 3.85 \\
\hline $65-74$ & 97 & 22 & 22.67 \\
Men & 54 & 19 & 35.18 \\
Women & 43 & 3 & 6.98 \\
\hline$>75$ & 17 & 5 & 29.41 \\
Men & 8 & 3 & 37.5 \\
Women & 9 & 2 & 22.22 \\
\hline
\end{tabular}

Table 4. Risk factors and development of abdominal aortic aneurysm

\begin{tabular}{|l|l|l|}
\hline Variables & $\mathrm{r}$ & $\mathrm{p}$ \\
\hline Sex & 0.199 & $0.04^{*}$ \\
\hline Hypertension & 0.292. & $0.007^{* *}$ \\
\hline Diabetes & -0.265 & 0.06 \\
\hline Dyslipidemia & 0.175 & 0.360 \\
\hline Asymptomatic carotid stenosis & 0.285 & $0.009^{* \%}$ \\
\hline Smoking & 0.317 & $0.002^{* *}$ \\
\hline Age & 0.648 & $0.000^{* *}$ \\
\hline
\end{tabular}

* statistical significance at 0.05 level;

** statistical significance at 0.01 level

Table 5. Variables significantly correlate to development of abdominal aortic aneurysm

\begin{tabular}{|l|l|l|l|l|}
\hline Analyzed variables & $\mathrm{t}$ & $\begin{array}{l}\text { Beta } \\
\text { Coefficient }\end{array}$ & $\mathrm{SE}$ & $\mathrm{p}$ \\
\hline Sex & 0.819 & 0.071 & 0.148 & 0.415 \\
\hline Hypertension & 0.947 & 0.124 & 0.196 & 0.234 \\
\hline Smoking & 6.528 & 0.592 & 0.012 & $0.002^{* *}$ \\
\hline Age & 6.958 & 0.619 & 0.007 & $0.000^{* *}$ \\
\hline $\begin{array}{l}\text { Asymptomatic } \\
\text { carotid stenosis }\end{array}$ & 0.477 & 0.045 & 0.151 & 0.639 \\
\hline
\end{tabular}

**: statistical significance at 0.01 level

and 19 women), with an average diameter of $27.12 \pm 1.62$ $\mathrm{mm}$ (Table 2).

Aneurysm of the abdominal aorta was found in 31 patients ( 25 men and 6 women), or $15.5 \%$ of all patients with average diameter of $43.73 \pm 10.39 \mathrm{~mm}$, i.e., $22.32 \%$ men with average diameter of $44.1 \pm 9.59 \mathrm{~mm}$ and $6.81 \%$ women with average diameter of $42.73 \pm 12.77 \mathrm{~mm}$. The mean age of patients with AAA was $76.34 \pm 7.49 \mathrm{~mm}$. On average, men with AAA were significantly younger than women with
AAA (73.97 $\pm 7.49 \mathrm{~mm}$ vs. $77.36 \pm 6.36 \mathrm{~mm}$; t-test, $\mathrm{p}=0.018)$ Small aneurysm, i.e., aneurysm with a 30 to $49 \mathrm{~mm}$ diameter, was found in 19 patients ( 14 men and 5 women), or $9.5 \%$ of the total number of patients, whereas AAA above $49 \mathrm{~mm}$ was found in 12 patients ( 11 men and 1 woman), or $6 \%$ of the total number of patients. Ten patients ( 9 men and 1 woman), or $5 \%$ of the total number of patients, underwent a successful surgery.

The prevalence of AAA increased significantly with age ( $\mathrm{x} 2$ test, $\mathrm{p}=0.008$ ). The increase was most pronounced above 65 years in men and 75 years in women (Table 3 ).

The patients with asymptomatic carotid stenosis had a significantly larger average diameter of the abdominal aorta compared to patients who had symptomatic carotid stenosis $(29.03 \pm 11.62 \mathrm{~mm}$ vs. $26.95 \pm 8.29 \mathrm{~mm}$; t-test; $\mathrm{p}=0.005)$. AAA had a significantly higher prevalence in patients with asymptomatic carotid stenosis ( 20 vs. $11, \chi^{2}$ test, $\mathrm{p}=0,023)$. This difference was significant with men (17 vs. 8 ; $\mathrm{x}^{2}$ test, $\left.\mathrm{p}=0,039\right)$ but not women.

The correlation analysis showed no correlation between the extent of carotid stenosis and AAA (correlation test, $\mathrm{p}<0.05$ ). That is, there was no correlation between patients with a severe type of carotid stenosis and an increased prevalence of AAA or vice versa.

Patients with both carotid stenosis and AAA had a significantly higher prevalence of hypertension ( 24 or $77.42 \%$, $\chi^{2}$ test, $\mathrm{p}=0.005$ ) and smoking (28 or $90.32 \%, \chi^{2}$ test, $\mathrm{p}=0.000$ ). The average diameter of the aortic aneurysm did not differ between current smokers $(46.79 \pm 11.4 \mathrm{~mm})$ and former smokers $(43.89 \pm 8.75 \mathrm{~mm})$ ( $\mathrm{t}$-test, $\mathrm{p}=0.628)$; however, both of these groups had aortic aneurysm diameters that were significantly larger than those of non-smokers $(36.33 \pm 3.21 \mathrm{~mm}$; t-test, $\mathrm{p}=0.021$ for current smokers and $\mathrm{p}=0.035$ for former smokers). Patients with diabetes $(40.82 \pm 9.15 \mathrm{~mm})$ had a significantly smaller average diameter of AAA than patients who did not have diabetes (47.20 $\pm 10.62 \mathrm{~mm}$; t-test, $\mathrm{p}=0.047)$.

The univariate correlation analysis showed that asymptomatic carotid stenosis $(\mathrm{r}=0.285, \mathrm{p}=0.009)$, smoking $(\mathrm{r}=0.317$, $\mathrm{p}=0.002)$, hypertension $(\mathrm{r}=0.292, \mathrm{p}=0.007)$, a male sex $(\mathrm{r}=0.199, \mathrm{p}=0.04)$ and an increasing age $(\mathrm{r}=0.648, \mathrm{p}=0.000)$ had significant positive correlations with the onset of AAA in patients with carotid stenosis. Dyslipidaemia $(r=0.175, \mathrm{p}=0.360)$ was not presented as a risk factor that had a significant correlation with the onset of AAA. Diabetes presented a negative correlation with the onset of AAA ( $r=-0.265, \mathrm{p}=0.06)$, but the difference did not reach statistical significance (Table 4). The multivariate regression analysis indicated that age $(\mathrm{p}=0.000)$ and smoking $(\mathrm{p}=0.002)$ were risk factors that independently affected the onset of AAA (Table 5).

\section{DISCUSSION}

To date, abdominal ultrasound is the most practical method for identifying AAA (8). The time needed to perform abdominal ultrasound and measure the aortic di- 
ameter is less than 10 minutes (9). The best therapy for AAA is presymptomatic elective surgery of carefully chosen patients. Despite having different methodologies, a recent meta-analysis and a randomised general population screening study aimed at detecting asymptomatic AAA and timely intervention both showed a significant reduction in AAA-related mortality $(8,10)$. However, a recent analysis of 16 studies that investigated the cost efficiency of AAA screening (11) failed to provide definitive recommendations for the population groups in which abdominal aorta screening should be performed.

The prevalence of AAA in the general population is approximately $4-10 \%$ for men over 60 years of age and $0.5-3 \%$ for women over 80 years of age $(8,12-15)$. However, it is very difficult to compare the results of these studies because of the differences in the study samples, methodology, and definitions of AAA.

The comorbidity of carotid stenosis and AAA and the prevalence of AAA in patients with carotid disease have been rarely studied. It was shown that carotid intima media thickening in patients with AAA was higher than that in the healthy population but lower than that in patients with peripheral artery disease $(16,17)$. The $15.5 \%$ prevalence of AAA in patients with carotid stenosis that we found in this study is higher than the prevalence found by Carty et al. (11\%) (18) and Kurvers et al. (6.5\%) (19), lower than the prevalence found by Karanjia et al. (20.22\%) (20) and Barba et al. (21.2\%) (21) and similar to the prevalence found by Kang et al. (22) (patients with carotid stenosis over $50 \%, 18.2 \%$; patients with carotid stenosis below $50 \%, 12.2 \%$; only patients without diabetes were included in the study). However, if one takes into consideration that our study included a similar number of men and women, whereas the number of men was much higher in the previous studies, then one can consider that the present results are in agreement with the findings of Karanjia et al. and Barba et al. $(20,21)$. In our study, the prevalence of AAA was significantly higher in men (22.32\%) than in women (6.81\%). However, this can be explained by the fact that AAA occurs much later in women than in men $(23,24)$, and the mean age was similar between men and women in this study. Indeed, men with aneurysm were significantly younger than women with AAA in this study. The prevalence of AAA significantly increases with age in both sexes, but the largest number of aneurysms was found in men over 65 years of age and in women over 75 years of age.

The average AAA diameter was significantly larger in patients with asymptomatic carotid stenosis than in patients with symptomatic carotid stenosis. The patients with asymptomatic carotid stenosis had been diagnosed with peripheral arterial disease, whereas the patients with symptomatic carotid stenosis had been diagnosed with cerebrovascular disease. Previous studies have shown that patients with peripheral arterial disease have a high prevalence of AAA (21), but the same was not shown with cerebrovascular disease.
Most of our patients $(9.5 \%$ of total number of examined patients, and $61.29 \%$ of patients with AAA) who had AAA also had a small AAA, with a typical diameter of 30 to $49 \mathrm{~mm}$. Aneurysms of this size do not require surgical intervention, but only periodic monitoring of the aneurysm growth, which had been performed. A small number of patients $(12,6 \%$ of all examined patients, and $38.71 \%$ of patients with AAA) had an aneurysm with a diameter of $49 \mathrm{~mm}$. Of these 12 patients, 10 (9 men and one woman, $5 \%$ of all patients) underwent successful surgery. One patient did not undergo surgery for his AAA, which did not exceed $5.5 \mathrm{~mm}$, whereas another patient did not undergo surgery due to a recent myocardial infarction and a poor cardiovascular status.

No correlation was found between the size of an AAA and the severity of carotid stenosis, i.e., it was not shown that patients with a more severe form of carotid stenosis also had a higher prevalence of AAA and vice versa. This finding is consistent with the data published by Kang et al. (22).

Carotid disease and AAA share many risk factors. Our results show a significant positive correlation between hypertension, smoking, age, male sex and asymptomatic carotid stenosis and the development of AAA. Furthermore, the male sex, age and smoking are factors that independently influence the development of AAA. The presence of diabetes showed a negative correlation with the development of AAA, but the difference was not statistically significant.

All studies so far have shown that AAA has a much higher prevalence above the age of 65 . It is interesting that there are many studies dealing with development of AAA only in men, which likely stems from the previous opinions that AAA is an extremely rare event in women and that aneurysmal arterial disease in women differs from that in men. The fact is that AAA develops in women after menopause, myocardial infarction, or stroke. However, the latest research (23) confirmed AAA is usually not diagnosed or is misdiagnosed in women and that operated women had a far worse postoperative outcome with procedures for a ruptured AAA. The risk factors in women do not differ significantly than those in men.

We have indicated that smoking is an independent risk factor for the development of AAA, and this finding is in compliance with other studies. An analysis of ten studies with over one million patients who smoked reported a prevalence of AAA that was 2.5 and 3.5 times higher than those for coronary disease and cerebrovascular disease, respectively (25). It appears that smoking is a greater risk factor for the development of aneurysms than for obstructive arterial disease. The smoking-mediated dysfunction of endothelium could be the underlying mechanism through which smoking triggers the development and growth of an AAA, resulting in a reduction in tissue-type plasminogen activator, which in turn leads to hypercoagulability (26). There are indicators that smoking cigarettes is a cause of inflammation, which is expressed through increased lev- 
els of circulating leucocytes, C-reactive protein, interleukin 6 and fibrinogen (27). Signs of inflammation were also present in passive smokers (28). Smoking cigarettes deteriorates the elasticity of the ascending aorta (29), whereas long-term smokers have reduced distensibility of the ascending aorta compared to non-smokers (29).

Diabetes is the most interesting rick factor for the development of AAA. Among the patients who had an abdominal aorta examined for the presence of aneurysm, $54.5 \%$ also had diabetes. However, if only patients with AAA are considered, then the diabetes prevalence drops to a mere $16.13 \%$. On the other hand, in the patients with AAA, those with diabetes had a significantly smaller AAA diameter than the AAA patients without diabetes. The univariate correlation analysis revealed a negative correlation between diabetes and the development of AAA, but that difference was not significant. In other words, the results of this study indicated the presence of diabetes has a protective effect on the development of AAA. The connection between AAA and diabetes is not clear, but it is thought that reduced monocyte activity and reduced production of matrix metalloproteinases, as observed in diabetes, may play a protective role in AAA (30). A negative association between diabetes and AAA, meaning that diabetes plays a protective role in the development and expansion of AAA, was noted early as 1995 (31), and this was confirmed in a number of patients (32). It was recently shown that the diameter of the aorta has an inverse relationship with the serum glucose concentration (33) and that diabetes reduces the progression of AAA (30).

Aneurysm of abdominal aorta is a disease that differs by its aetiology, pathogenesis, clinical picture, risk factors and therapy from arterial occlusive disease (such as carotid disease), although the both diseases include degenerative atherosclerotic changes within the blood vessel wall. However, numerous factors affect the course of events in developing arterial occlusive disease (disease of endothelium) or aneurysmal arterial disease (collagen and elastin disease).

The results of this study and a small number of other studies that focused on the prevalence of AAA in patients with carotid stenosis indicate different prevalence rates for AAA in these patients, even for patients with stenosis of less than $50 \%$, which does not have to be considered as clinically significant. Therefore, screening these patients for the existence of AAA could be useful in reducing the mortality resulting from the rupture of AAA.

\section{REFERENCES}

1. Johnston KW, Rutherford RB, Tilson MD. (1991). Suggested standards for reporting on arterial aneurysms. Subcommittee on Reporting Standards for Arterial Aneurysms, Ad Hoc Committee on Reporting Standards, Society for Vascular Surgery and North Am Chapter, International Society for Cardiovascular Surgery. J Vasc Surg. 13:452- 458.
2. Grange JJ, Davis V, Baxter BT. (1997). Pathogenesis of abdominal aortic aneurysm: an update and look toward the future. Cardiovasc Surg. 5:256-265

3. Thompson RW. (2003). Basic science of abdominal aortic aneurysms: emerging therapeutic strategies for an unresolved clinical problem. Curr Opin Cardiol. 11:504-518

4. Ailawadi G, Eliason JL, Upchurch Jr GR.(2003). Current concepts in the pathogenesis of abdominal aortic aneurysm. J Vasc Surg. 38:584-588

5. Wilmink AB, Forshaw M, Quick CR. (2002). Accuracy of serial sceening for abdominal aortic aneurysms by ultrasound. J Med Screen. 9:125-1277

6. Kent KC, Zwolak RM, Jaff MR et al for the Society for Vascular Surgery, American Association of Vascular Surgery, and Society for Vascular Medicine and Biology. (2004). Screening for abdominal aortic aneurysm: a consensus statement. J Vasc Surg. 39:267-9

7. Filis K, Arko F, Johnson B. (2002). Duplex Ultrasound Criteria for Defininig the Severity of Carotid Stenosis. Ann Vasc Surg. 25:875-879

8. Fleming C, Whitlock EP, Beil TL. (2005). Screening for abdominal aortic aneurysm: a best-evidence systematic review for the US Preventive Services Task Force. Ann Intern Med. 142:203-211

9. Bruce CJ, Spittell PC, Montgomery SC. (2000). Personal ultrasound imager: abdominal aortic aneurysm screening. J Am Soc Echocardiology. 13:674-679

10. Tagaki H, Tanabashi T, Kawai N. (2008). Screening for abdominal aortic aneurysm reduces both aneurysm-related and all-cause morality. J Vasc Sur. 46(6):1311-2

11. Ehlers L, Sorensen J, Jensen LG. (2008). Is population screening for abdominal aortic aneurysm cost-effective? BMC Cardiovasc Disord. 18:8-32

12. Moore CL, Holliday RS, Hwang JQ. (2008). Screening for abdominal aortic aneurysm in asymptomatic at risk patients using emergency ultrasound. Am J Emerg Med. 26(8):83-7

13. Scott RA. (2008). The place of screening in the management of abdominal aortic aneurysm. Scand J Surg. 97(2):136-8

14. Kim LG, Scott RA, Ashton HA. (2007). Multicentre Aneurysm Screening Study Group. A sustained mortality benefit from screening for abdominal aortic aneurysm. Ann Intern Med. 146:699-706

15. Spurgeon D. (2004). US screening programme shows high prevalence of abdominal aortic aneurysm. BMJ. 328:852.

16. Cheuk BL, Lau SS, Cheng SW. (2007). Carotid intima media thickness in patients with abdominal aortic aneurysm. Eur Vasc Endovasc Surg. 33(2):149-53

17. Simons PC, Algra A, Bots ML. (1999). Common carotid intima media thickness in patients with peripheral arterial disease or abdominal aortic aneurysm: the SMART study. Second Menifestation of ARTrial disease. Atherosclerosis. 146(2):243-8 
18. Carty GA, Nachtigal T, Magyar R. (1993). Abdominal duplex ultrasound screening for occult aortic aneurysm during carotid arterial evaluation. J Vasc Surg. 17(4):696-702

19. Kurvers HA, van der Graaf Y, Blankenstejn JD; SMART StudyGroup. (2003). Screening for asymptomatic internal carotid artery stenosis and aneurysm of abdominal aorta: comparing the yield between patients with manifest atherosclerosis and patients with risk factors for atherosclerosis only. J Vasc Surg. 37(6): 1226-33.

20. Karanjia PN, Madden KP, Lobner S. (1994). Coexistence of abdominal aortic aneurysm in patients with carotid stenosis. Stroke. 25(3):627-30

21. Barba A, Estallo L, Rodrigez L. (2005). Detection of abdominal aortic aneurysm in patients with peripheral artery disease. Eur Vasc Endovasc Surg. 30:504-508.

22. Kang SS, Littooy FN, Gupta SR. (1999). Higher prevalence of abdominal aortic aneurysms in patients with carotid stenosis but without diabetes. Surgery. 126(4):687-91

23. Lederle FA, Larson JC, Margolis KL; Women's Health Initiative Cohort Study. (2008). Abdominal aortic aneurysm events in the women's health initiative. BMJ. 14;337:a1724

24. Vouyouka AG, Kent KC. (2007). Arterial vascular disease in women. J Vasc Surg. 46(6): 1295-302

25. Lederle FA, Nelson DB, Joseph AM. (2003). Smoker's relative risk for aortic aneurysm compared with other smoking-related diseases: A systematic review. J Vasc Surg. 38:329-334
26. Benowitz NL. (2003). Cigarette smoking and cardiovascular disease: Pathophysiology and implications for treatment. Prog Cardiovasc Dis. 46:91-111

27. Tuut M, Hense HW. (2001). Smoking, other risk factors and fibrinogen levels: Evidence of effect modification. Ann Epidemiol. 11:232-238

28. Yuan H, Wong LS, Bhattacharya M. (2007). The effects of second hand smoke on biological processes important in atherogenesis. BMC Cardiovasc Disord. 7:1

29. Sassalos K, Vladchopoulos C, Alexopoulos N. (2006). The acute and chronic effect of cigarette smoking on the elastic properties of the ascending aorta in healthy male subjects. Hellenic J Cardiol. 47:263-258

30. Golledge J, Norman PE. (2008). Diabetes and aortic aneurysm. The American Journal of Cardiology. 1;101(11):1680-1681

31. La Morte WW, Scott TE, and Menzoian JO (1995). Racial differences in the incidence of femoral bypass and abdominal aortic aneurysmectomy in Massachusetts: relationship to cardiovascular risk factors. J Vasc Surg. 21: 422-431

32. Lederle FA, Johnson Gr, Wilson SE. (1997). Prevalence and associations of abdominal aortic aneurysm detected trough screening. Aneurysm Detection and Manangement (ADAM) Veterans Affairs Cooperative Study Group. Ann Intern Med. 126(6):441-449

33. Le MTQ, Jamrozik K, Davis TM. (2007). Negative association between infra-renal aortic diameter and glicaemia: the health in men study. Eur J Vasc Endovasc Surg. 33:592-598 